\title{
Effect and interaction of crop management factors and crop year on the yield of maize (Zea mays L.)
}

\author{
Karamchand Bramdeo - Tamás Rátonyi \\ University of Debrecen, Faculty of Agricultural and Food Sciences and Environmental Management, \\ Institute of Land Use, Technology and Regional Development \\ bramdeo@agr.unideb.hu
}

\begin{abstract}
SUMMARY
The aim of this study was to determine the combination of treatment levels of crop management factors which can optimize and sustain maize yield under varying climatic conditions. The effect of winter wheat forecrop, three tillage systems (Mouldboard-MT, Strip-ST, Ripper-RT), two planting densities $\left(60,000 \& 80,000\right.$ plants ha $\left.{ }^{-1}\right)$, three fertilizer levels $\left(N_{0}\right.$-control, $\left.N_{80}, N_{160} \mathrm{~kg} \mathrm{ha}^{-1}\right)$ with four replications in irrigated and non-irrigated treatments were evaluated over a five year period, 2015-2019. The obtained results revealed that growing season rainfall positively correlated with yield, whereas, temperature negatively correlated with yield. Impact of adverse weather on yield was less severe in biculture, irrigated plots, at lower planting density (60,000), lower fertilizer rate (N80) and in RT and ST, compared to MT. In years with favorable rainfall, yields of MT and RT were significantly $(P<0.05)$ higher than ST. However, in a less favorable year, such as 2015 , with 299 mm growing season rainfall and the lowest July rainfall (59\% below mean) there was no significant difference (P>0.05) in yield among the three tillage treatments. Higher planting density (80,000), and fertilization rate (N160) in tandem with MT are treatments combination conducive for high yield under favorable climatic conditions, whereas, in years with low rainfall and high temperatures, RT and ST offer alternative to MT for optimum yield with 60,000 plants ha ${ }^{-1}$ and N80 treatment level. Crop year effect accounted for $20.7 \%$ of yield variance, fertilization $35.8 \%$, forecrop $12.8 \%$, plant density $3.4 \%$, tillage $1.2 \%$ and irrigation $<1 \%$. It is conclusive that with proper selection of the appropriate levels of agrotechnological inputs the adverse effect of weather on yield can be mitigated.
\end{abstract}

Keywords: tillage, fertilizer, crop rotation, irrigation, plant density

\section{INTRODUCTION}

Maize (Zea mays L.) is a major grain crop with a variety of use. In addition to being utilized as a source of feed, food and fuel, its industrial usages are increasingly expanding. In Hungary, maize is cultivated on approximately one million ha, with yield over the last decade ranging between 3.7-8.5 tons ha $^{-1}$ (Hungarian Central Statistical Office, 2019). The significant fluctuation justifies the need for improving and stabilizing the yield of maize. In addition to weed control, pests and diseases management, hybrid selection and planting date, other integral crop production practices include tillage, irrigation, fertilization, planting density and crop rotation, all of which have significant impact on maize yield. The extent of impact on yield is modified by the effect of the crop year and therefore the aim of this research is to evaluate and determine the combination of treatments levels of crop management factors, which can optimize and sustain yield under varying climatic conditions (2015-2019).

Yield is ultimately determined by the level of interactions between the agroecological, agrotechnological and biological base and therefore harmonization of these factors are fundamental for achieving high and stable yield. The effect size of agrotechnical inputs are strongly modified by crop years as a result of variability in amount and distribution of precipitation coupled with temperature, hence optimization of agrotechnical inputs can help to offset harmful climatic effects. Weather regulates heat and moisture supply of the crop environment and therefore influences material transformation, fertilizer efficiency and nutrient uptake by plants (Sárvári and Pepó, 2014).

Tillage is an agrotechnical input, which has significant influence on soil physical, chemical and biological properties and impacts on plant growth and development. According to Grassini et al. (2011), soil tillage and crop rotation are the most important factors affecting maize yield besides sowing and planting density. Conventional tillage is the most widely used and popular tillage system in Hungary. However, due to environmental concerns and high costs of conventional tillage, focus is being placed on alternative tillage methods, such as reduced tillage, minimum tillage and no-till. The shift from conventional to conservation tillage methods has several advantages such as soil and water conservation, reduction in fuel costs and minimizing soil erosion. Long-term research in Kansas, USA has shown that maize can be grown successfully in conservation tillage systems with careful management and planning (Rogers et al., 2007). Deep tillage followed by conventional tillage had taller plants, produced more cobs plant ${ }^{-1}$ with significantly higher corn yields than in no-till and minimum till, respectively (Memon et al., 2012). Soil tillage systems had different effects on the preservation of the soil moisture contents, which significantly affected maize yield (Simić et al., 2009). Kristo et al. (2013) reported that under extremely dry conditions the height of the maize plant, the number of cobs, length of cob, fertility of cob, number of grains per cob and the final yield were significantly affected by the soil tillage system.

Accompanying significant yield increase over the years, plant population density of maize (Zea mays L.) 
has also increased substantially, since the introduction of hybrid maize in 1930. Plant density has a determining effect on yield and increasing it, increases yield up to a maximum for a given maize genotype (Tollenaar et al., 1994). Higher planting density increases leaf area index and consequently water consumption (Tetio-Kagho and Gardner, 1988). Maize grain yield declines when plant density is increased beyond the optimum plant density primarily because of decline in the harvest index and increase stem lodging (Tokatlidis and Koutrubas, 2004). Plant density had significant effect on grain yield, plant height, number of kernels ear ${ }^{-1}$, number of grains ear row $^{-1}$, harvest index, number of cobs plant ${ }^{-1}$, cob length, ear diameter and stem diameter (Sharifi et al., 2009; Abuzar et al., 2011). In Hungary, the optimum plant density was lower in dry years $\left(50,000\right.$ plants $\left.\mathrm{ha}^{-1}\right)$ and higher $\left(80,000\right.$ plants $\left.\mathrm{ha}^{-1}\right)$ in years with favorable rainfall (Pepó et al., 2008; Berzsenyi et al., 2011).

Crop rotation in maize production optimizes yield potential by improving soil fertility, water availability, root penetration, reducing weeds, diseases and pest populations. Suitable crop rotation is of particular importance in maize production, since it is the most effective method of control against the larva of the American maize bug and also because water usage and nutrient such as zinc can become over-restricted in monoculture maize, leading to drastic reduction in yield (Brankatschk and Finkbeiner, 2017). Crop rotation can help in the successful use of minimum tillage and decrease the costs of production with fewer inputs and can strongly modify the efficiency of fertilization (Sárvári, 2005). Good preceding crops for maize in Hungary includes winter wheat, winter barley, spring barley, triticale, potato, rape, leguminous plants. The effect of weather (precipitation) and irrigation (artificial water supply) on the yield of maize was significantly influences by crop rotation and was more pronounced in monoculture with the lowest yield, compared to biculture and triculture maize (Pepó et al., 2008).

Nitrogen is a vital plant nutrient and a major yield determining factor required for maize production. Its deficiency or excess can result in reduced yield (Shanti et al., 1997). In non-irrigated treatments in Hungary, 90 $\mathrm{kg} \mathrm{N} \mathrm{Na}^{-1}$ fertilizer dose was found to be adequate to achieve yield that are close to maximum, while in irrigated treatments upto $120 \mathrm{~kg} \mathrm{~N} \mathrm{ha}^{-1}$ (Nagy, 2003). Bocz and Nagy (1981) reported that optimal N-supply significantly contributes to grain number per cob, and to a lesser extent increase of thousand grain weight. According to Inamullah et al. (2011), increasing nitrogen levels up to $240 \mathrm{~kg} \mathrm{ha}^{-1}$, increased ears plant ${ }^{-1}$, ear length, grains ear ${ }^{-1}, 1000$ grain weight, biological yield, grain yield and harvest index. Similar results were also reported by and Shivay and Singh (2000), who attributed the significant increase in plant height and crop yields of maize to the increased cell division and enlargement caused by addition of $\mathrm{N}$ fertilization. Interaction of nitrogen fertilization and irrigation have significant impact on grain yield and water use efficiency. Water utilization of the maize can be improved with proper nutrient supply and optimum fertilization (Pepó and Karancsi, 2014). Megyes (2005) found that both fertilization and irrigation had significant effect on the yield and the yield-increasing effect of irrigation and fertilization differed significantly with crop years. Similar report by Sulyok (2005) showed that higher yields were achieved with $240 \mathrm{~kg} \mathrm{~N} \mathrm{ha}{ }^{-1}$ in years with high precipitation, compared to dry years, where $240 \mathrm{~kg} \mathrm{~N}$ treatment resulted in yield depression. Berzsenyi (2010) reported fertilization on maize yields in dry and wet years revealed very substantial effect of the year on the yield and the wet years was $2.4 \mathrm{t} \mathrm{ha}^{-1}$ greater than the dry years. The yield increasing effect of irrigation on fertilization can be explained with the positive correlation between nutrient and water supply (Nagy, 2007). In addition to rainfall amount in a crop year, the distribution significantly affects yield and lower yields are not always linked to drought years, but higher yields usually occur in wet years due to better water supply which allows for improved fertilizer utilization (Nagy, 2007). Li et al. (2019) observed in the USA that excessive rainfall can impact positively or negatively on yield, depending on the region. In cooler areas with poorly drained soils and high preseason soil water storage, excessive rainfall was found to significantly decrease yield.

Evaluating the effects and interactions of the agrotechnical inputs and crop years on yield of maize will provide valuable information which will allow for better harmonization of agroecological conditions and crop production technologies, thus leading to improvement in grain production and yield stability.

\section{MATERIALS AND METHODS}

The experiment was setup in 2015 in a split-plot design at Látókép Research Station, site (N 47³3' E $\left.21^{\circ} 27^{\prime}\right)$ as part of an ongoing long-term experiment and repeated annually until 2019. The soil type was calcareous chernozem, consisting of $11 \%$ sand, $65 \%$ silt and $24 \%$ clay in the upper soil layers, with a near neutral $\mathrm{pH}$ value $\left(\mathrm{pH}_{\mathrm{KCl}}=6.46\right)$. It had a humus content of $2.8 \%$ and humus depth of approximately $80 \mathrm{~cm}$, with good water holding capacity. The experimental area had a dimension of $122.7 \mathrm{~m} \mathrm{x} 272.0 \mathrm{~m}$ and consisted of three main blocks, each with one of the three tillage treatments (Mould board (MT)-30 cm, Strip Tillage (ST)-25 cm and Ripper Tillage (RT) $-45 \mathrm{~cm}$ ). The size of each tillage block was $9,928 \mathrm{~m}^{2}$ subdivided into two sections, irrigated and non-irrigated. The main tillage blocks were subdivided to accommodate biculture (maize-winter wheat) and monoculture (maize) treatments. The winter wheat area $(8.4 \mathrm{~m} \times 262 \mathrm{~m})$ in each of the three main tillage blocks was rotated with maize annually during the examined period.

Maize was sown with a Gaspardo 6-row seeding machine at 60,000 and 80,000 plants ha ${ }^{-1}$, with interrow spacing of $76 \mathrm{~cm}$ in April and treated with three levels of fertiliser treatments, $\mathrm{N}-0 \mathrm{~kg} \mathrm{ha}^{-1}$ (control), $\mathrm{N}$ $80 \mathrm{~kg} \mathrm{ha}^{-1}+\mathrm{P}-60 \mathrm{~kg} \mathrm{ha}^{-1}+\mathrm{K}-90 \mathrm{~kg} \mathrm{ha}^{-1}$ and N-160 kg $\mathrm{ha}^{-1}+$ P-60 kg ha-1 $+\mathrm{K}-90 \mathrm{~kg} \mathrm{ha}^{-1}$ with four random 
replications. There were 216 subplots for each of the main tillage blocks, and a grand total of 648 treatments $(216 \times 3)$ plots for the overall experiment.

Irrigation was applied in an amount that is close to the calculated need of the plant $(273 \mathrm{~mm})$ and was done with a self-propelled, $75 \mathrm{~cm}$ division linear sprinkler irrigation system, equipped with sensors to maintain uniformity in movement during operation.

The experimental plots were harvested with a two row Sampo Rosenlew-2010 harvester, that processed the cobs and separate the grains which were then weighed and recorded. Grain moisture of field samples was analysed using a GAC2100 electronic moisture tester. The moisture content was then corrected to $15 \%$ and the yield extrapolated to tonnes per hectare.

Daily temperature and precipitation data were recorded on site and monthly averages and totals computed for the examined period (2015-2019) and compared to the 10-year mean (Figure la-1e).

\section{Statistical evaluation method}

Yield data were analysed with Microsoft Excel and SPSS 26.0 programs and treatment means were compared using the Fisher's least significant difference (LSD) test $(\mathrm{P}<0.05)$.

Figures $1 a-1 e$ : Rainfall and temperature data in the investigated growing seasons, 2015-2019 (Látókép, Debrecen)

Figure 1a: Rainfall and temperature-2015

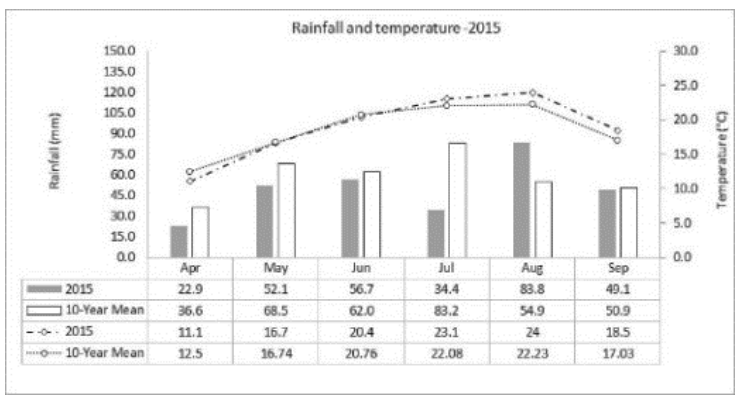

Figure 1c: Rainfall and temperature-2017

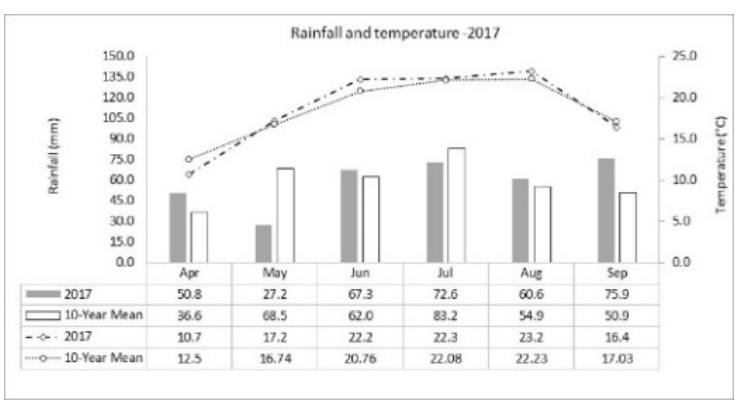

Figure $1 b$ : Rainfall and temperature-2016

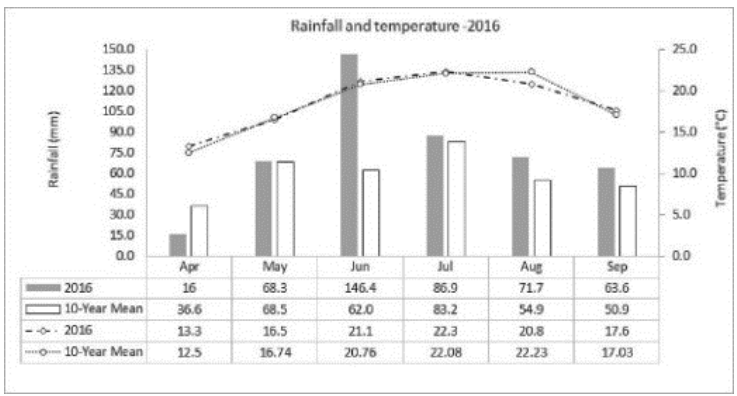

Figure $1 d$ : Rainfall and temperature-2018

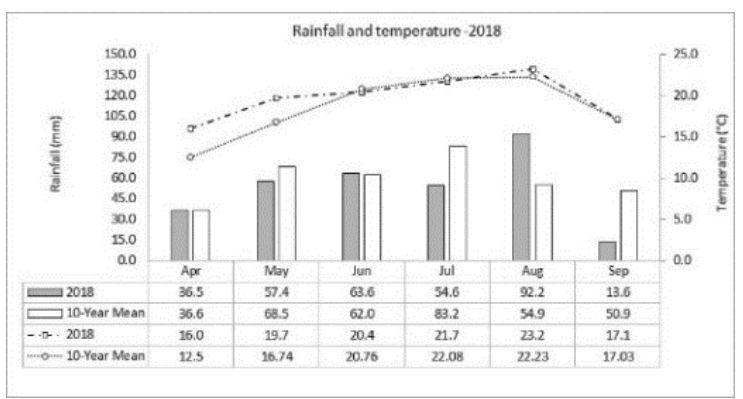

Figure 1e: Rainfall and temperature-2019

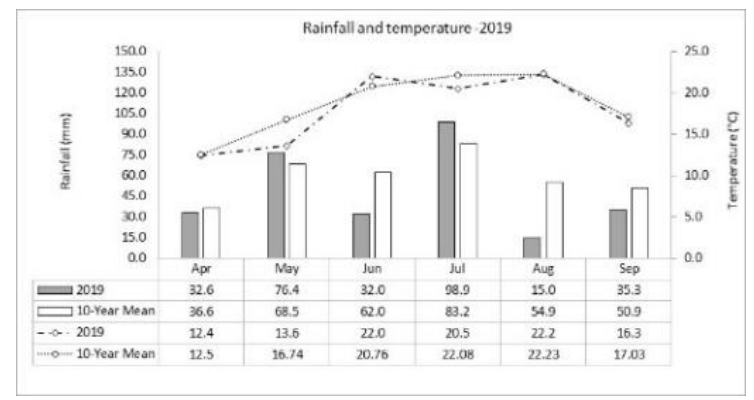

\section{RESULTS AND DISCUSSION}

Yield varied significantly $(\mathrm{P}<0.05)$ over the examined period, ranging from 8.36 to $12.43 \mathrm{t} \mathrm{ha}^{-1}$ with a mean of $10.08 \mathrm{t} \mathrm{ha}^{-1}$. Crop year effect accounted for $20.7 \%$ of yield variance with significant difference between years, apart from 2018 \& 2019 (Table 1). 
Tukey's HSD test of significance among crop years

\begin{tabular}{|c|c|c|c|c|c|c|}
\hline \multicolumn{7}{|c|}{ Yield (t ha-1) } \\
\hline & \multirow[t]{2}{*}{ Year } & & \multicolumn{4}{|c|}{ Subset } \\
\hline & & $\mathbf{N}$ & 1 & 2 & 3 & 4 \\
\hline \multirow[t]{6}{*}{ Tukey HSD $^{\mathrm{a}, \mathrm{b}}$} & 2015 & 648 & 8.3631 & & & \\
\hline & 2017 & 648 & & 9.1125 & & \\
\hline & 2019 & 648 & & & 10.1524 & \\
\hline & 2018 & 648 & & & 10.3487 & \\
\hline & 2016 & 648 & & & & 12.4282 \\
\hline & Sig. & & 1.000 & 1.000 & .665 & 1.000 \\
\hline
\end{tabular}

The error term is Mean Square (Error) $=6.924$.

a. Uses Harmonic Mean Sample Size $=648.000$.

b. Alpha $=.05$.

Annual rainfall (Oct-Sep) moderately correlated with yield ( $\mathrm{r}=0.68)$, whereas, growing season $(\mathrm{Apr}-$ Sep) rainfall displayed a stronger correlation $(\mathrm{r}=0.76)$ (Figure 2a). The strongest correlation $(\mathrm{r}=0.75)$ was observed in the month of June, while July rainfall showed the second highest correlation $(\mathrm{r}=0.61)$.

Results of long-term experiments showed July reportedly had the strongest correlation with yield, since it coincides with the most critical phase (flowering) of maize development (Nagy, 2012; Hodges, 1931). The deviation from July month during the examined period resulted from the abnormality of 2016 with very high precipitation in June (146.4 mm vs. $73.2 \mathrm{~mm}$ LTM) coupled with the significantly high yield $\left(\right.$ mean $\left.+2.35 \mathrm{t} \mathrm{ha}^{-1}\right)$. A test of correlation excluding 2016 confirm the findings of long-term experiment. Totals of monthly rainfall do not reveal the distribution within the months, likewise monthly averages of temperatures do not provide any indication of the timing as evident in 2017 (Figure 1c) where the average July temperature appears in line with the 10-year mean but yield was severely affected by high temperatures, reaching $35.9{ }^{\circ} \mathrm{C}$ between $17^{\text {th }}-24^{\text {th }}$ July, coupled with lack of rainfall between July $13^{\text {th }}-22^{\text {nd }}$.

Mean growing season temperature during the examined period negatively correlated $(\mathrm{r}=-0.11)$ with yield, and the strongest correlation $(r=-0.93)$ was observed in August. This observation also deviates from findings of long-term experiment which showed July temperature as having the strongest negative correlation and the main reason being the uniqueness of 2016 (Figure $2 b$ ). With the exclusion of 2016 data, the correlation analysis showed July having the highest negative correlation $(\mathrm{r}=-0.87)$ followed by August $(\mathrm{r}=-0.76)$. The adverse effect of high temperature in July was very evident in 2017. Yield in 2017 was significantly lower $\left(-1.19 \mathrm{t} \mathrm{ha}^{-1}\right)$ than in 2018 , although both growing seasons and July rainfall were significantly higher by $11.5 \%$ \& $33 \%$, respectively. Daily temperature from July $17^{\text {th }}-24^{\text {th }}$ was $4.89{ }^{\circ} \mathrm{C}$ above the mean and the situation was exacerbated by lack of rainfall. In Nebraska, USA, Wilhelm and Wortmann (2004) found that maize produced less grain with higher summer temperatures and yield increased with less spring and more summer rainfall. According to Hatfield and Dold (2018), productivity of maize is reduced when extreme temperature events occur during pollination and is further amplified when there are water deficits at pollination. Lobell and Asner (2003) reported yield of maize in the USA decreased by $17 \%$ for every $1^{\circ} \mathrm{C}$ increase in growing season temperature.

Figure $2 b$ : Correlation between yield and July temperature

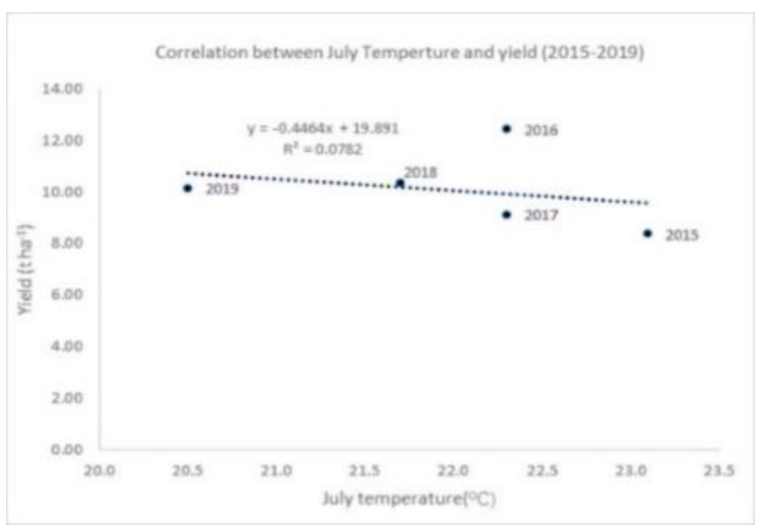


Yield in the tillage treatments varied with the crop years (Figure 3). MT yield showed stronger correlation $(\mathrm{r}=0.86)$ with the growing season rainfall, compared to RT ( $\mathrm{r}=0.79)$ and ST (r=0.33). Mean yield of ripper tillage (RT) was $2.3 \%$ higher $\left(0.232 \mathrm{t} \mathrm{ha}^{-1}\right)$ than that of mouldboard tillage (MT) and 8.2\% above Strip tillage (ST). Yield difference between RT and MT was not statistically significant $(\mathrm{P}>0.05)$, however, yields of both RT and MT were significantly $(\mathrm{P}<0.05)$ higher than ST (Table 2).

Figure 3: Yield of tillage treatments by year (2015-2019)

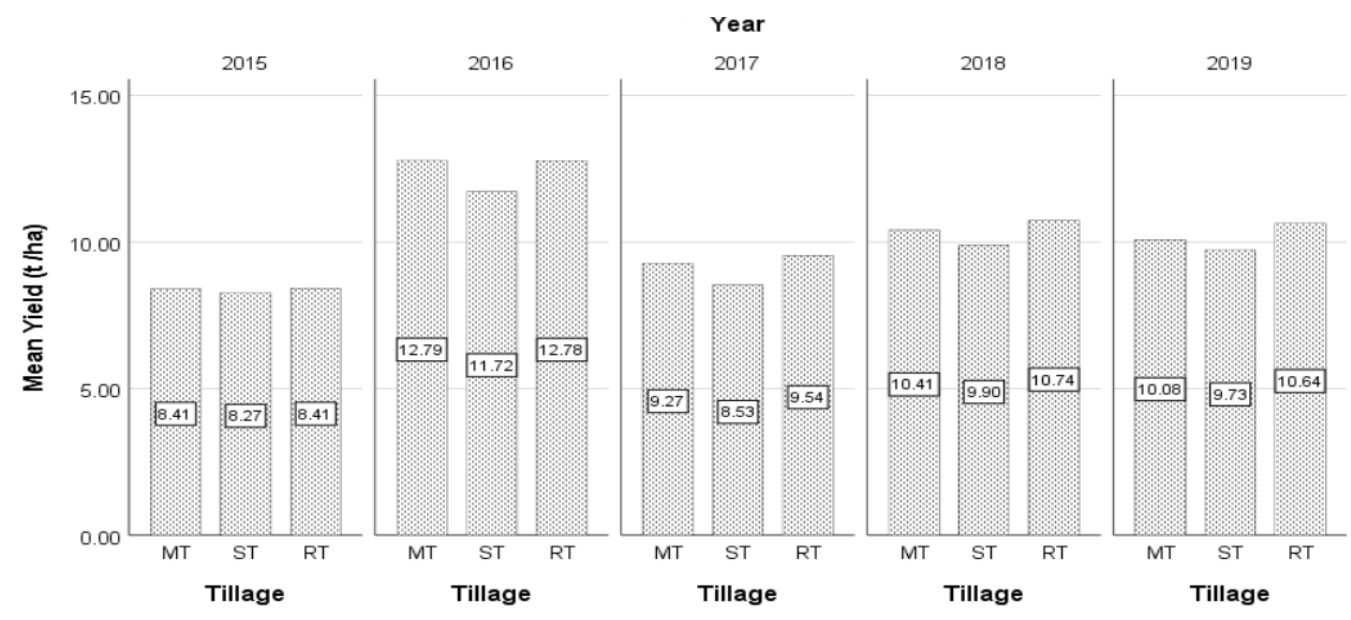

Table 2

Tillage treatments pairwise comparison

\begin{tabular}{|c|c|c|c|c|c|c|}
\hline \multicolumn{7}{|c|}{$\begin{array}{l}\text { Dependent Variable: Yield } \\
\text { LSD }\end{array}$} \\
\hline \multirow[b]{2}{*}{ (I) Tillage } & \multirow[b]{2}{*}{ (J) Tillage } & \multirow{2}{*}{$\begin{array}{c}\text { Mean } \\
\text { Difference (I-J) }\end{array}$} & \multirow[b]{2}{*}{ Std. Error } & \multirow[b]{2}{*}{ Sig. } & \multicolumn{2}{|c|}{ 95\% Confidence Interval } \\
\hline & & & & & Lower Bound & Upper Bound \\
\hline \multirow[t]{2}{*}{ Mouldboard Tillage (MT) } & Strip Tillage (ST) & $.5607^{*}$ & .12071 & .000 & .3240 & .7973 \\
\hline & Ripper Tillage (RT) & -.2317 & .12071 & .055 & -.4683 & .0050 \\
\hline \multirow[t]{2}{*}{ Strip Tillage (ST) } & Mouldboard Tillage (MT) & $-.5607^{*}$ & .12071 & .000 & -.7973 & -.3240 \\
\hline & Ripper Tillage (RT) & $-.7923^{*}$ & .12071 & .000 & -1.0290 & -.5557 \\
\hline \multirow[t]{2}{*}{ Ripper Tillage (RT) } & Mouldboard Tillage (MT) & .2317 & .12071 & .055 & -.0050 & .4683 \\
\hline & Strip Tillage (ST) & $.7923^{*}$ & .12071 & .000 & .5557 & 1.0290 \\
\hline
\end{tabular}

Based on observed means.

The error term is Mean Square(Error) $=7.868$.

*. The mean difference is significant at the .05 level.

In 2015, a year with relatively low rainfall, yield differences among tillage treatments were not statistically significant $(\mathrm{P}>0.05)$. The result suggests that RT and ST are more adaptable for drier condition and can be substituted for MT to aid conservation of soil moisture during drought. Impact of tillage on overall yield variance was relatively small $(2.9 \%)$ and could be attributed to the very good physical and chemical properties of chernozem soil at the experimental site. Tillage $\mathrm{x}$ forecrop interaction was significant and effect size varied with crop year. In 2017,2018 \& 2019 yield of maize in monoculture RT was significantly higher (7.0-9.6\%) than MT and there was no significant difference $(\mathrm{P}<0.05)$ in yield between MT and ST, except in 2016 (Figure 4).
Figure 4: Tillage $\mathbf{x}$ forecrop $\mathbf{x}$ year interaction (2015-2019)

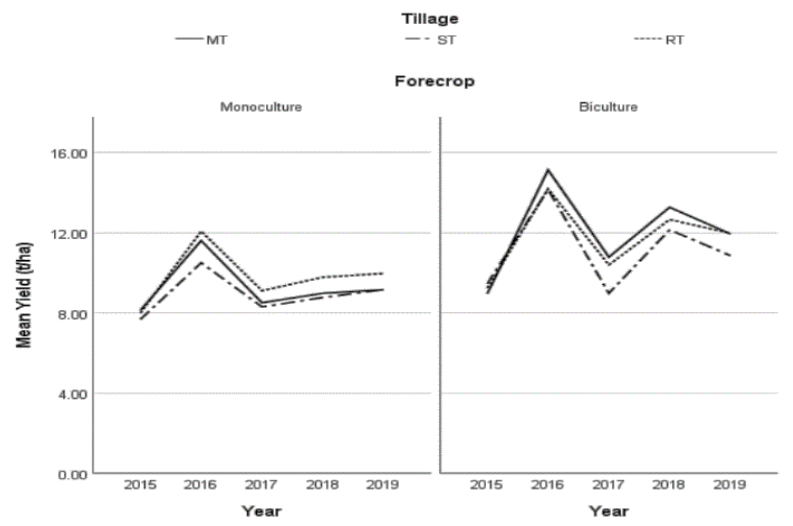


Overall mean yield of RT in monoculture was $5.5 \%$ higher than MT, while in biculture, yield of MT was $2.8 \%$ higher than RT (monoculture: $\mathrm{RT}>\mathrm{MT}>\mathrm{ST}$; biculture: $\mathrm{MT}>\mathrm{RT}>\mathrm{ST}$ ). The higher yield of RT in monoculture suggests it is more suitable for soil with lower nutritional status, as in the case of monoculture, with lower organic matter content, and by extension soil with higher bulk density. Its shattering and subsoiling effect is known to reducing bulk density and make subsoil resources available to the plant (Abidela, 2019; Al-Kaisi et al., 2015).

Tillage $\mathrm{x}$ irrigation $\mathrm{x}$ forecrop $\mathrm{x}$ fertilization interaction was statistically significant $(\mathrm{P}<0.05)$. Highest fertilizer use efficiency was observed in MT which was most responsive to irrigation and N160 treatments with the highest yield increment of 1.75 $\mathrm{t} \mathrm{ha}^{-1}$ in biculture; $1.10 \mathrm{t} \mathrm{ha}^{-1}$ in monoculture (Figure $5 a$ ), rendering it more suitable for favorable crop years and intensive maize production, as oppose to RT and
ST. Irrigation in monoculture tillage plots with N80 and No treatments adversely affected yield and was more pronounced in the control (N0) in particular, ST with the highest decline $\left(-1.58 \mathrm{tha}^{-1}\right)$, followed by MT (-0.87 $\left.\mathrm{t} \mathrm{ha}^{-1}\right)$ and RT with the least $\left(-0.65 \mathrm{tha}^{-1}\right)$. The positive impact of irrigation on fertilization $\mathrm{x}$ tillage interaction in biculture and negative impact in N0 and N80 in monoculture is in conformity with research findings that soil nutrient status in biculture maize is generally higher than monoculture and harmonization of irrigation and fertilization is necessary for optimum results (Megyes et al., 2005; Csajbók et al., 2014). It is well established that tillage practices influence soil moisture content and availability of nutrients to varying extent and ripper tillage allows for deeper root penetration and exploration of subsoil resources (Wang et al., 2015; Al-Kaisi et al., 2015; Schneider et al., 2017).

Figure 5 a-f: Interaction of irrigation $\mathbf{x}$ tillage $\mathbf{x}$ fertilization $\mathbf{x}$ forecrop on yield increment by crop year

Figure 5a: Mean 2015-2019

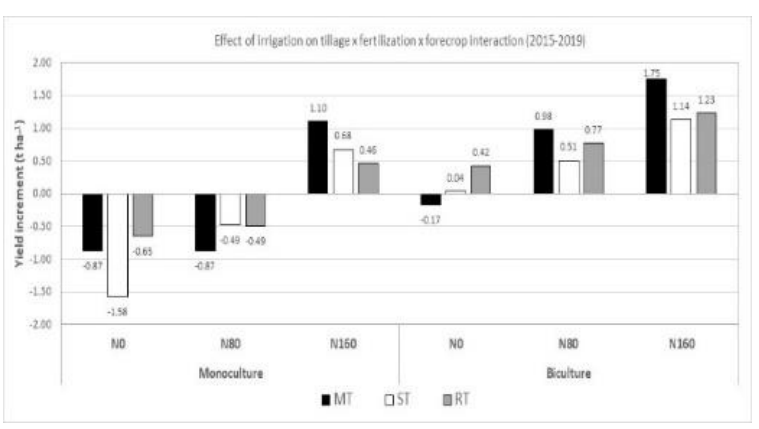

Figure 5c: $\mathbf{2 0 1 6}$

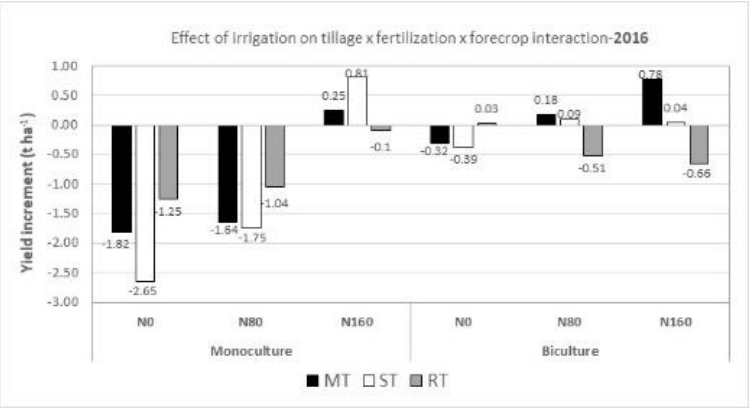

Figure 5e: $\mathbf{2 0 1 8}$

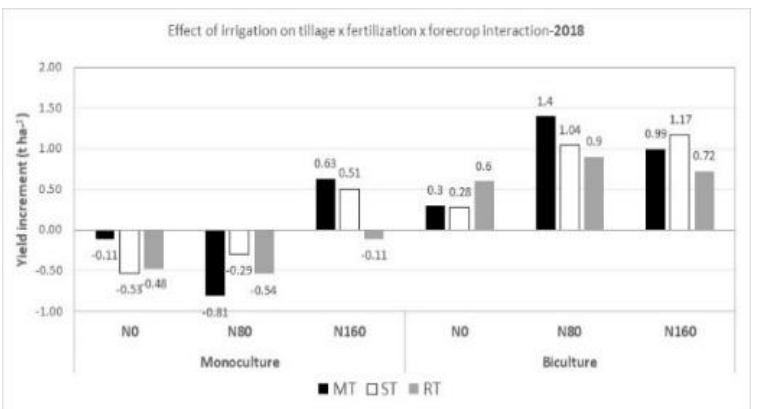

Figure 5b:2015

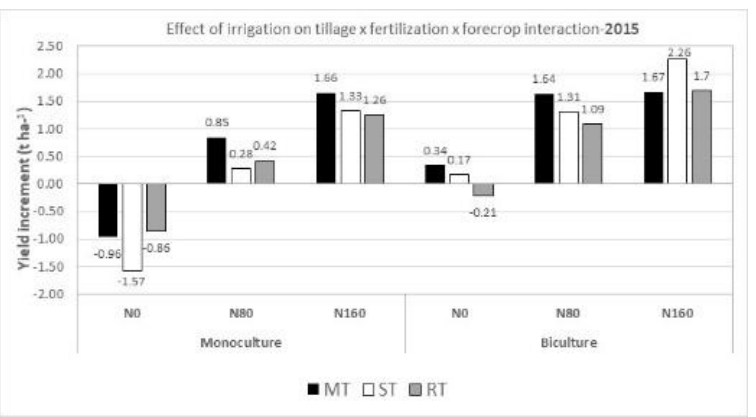

Figure 5d: 2017

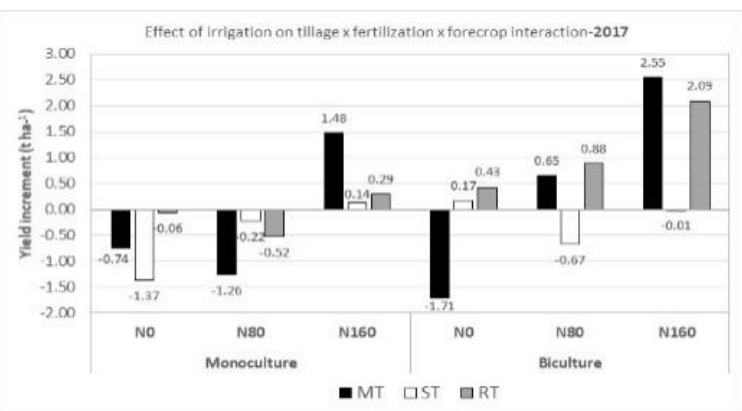

Figure 5f: 2019

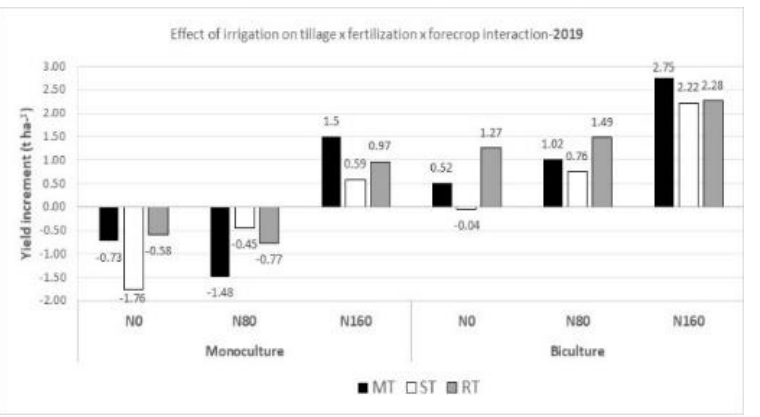


RT was least affected by irrigation in the control (N0) of monoculture plots, compared to ST and MT (Figure 5a). This could be attributed to the subsoiling effect of RT which allows for deeper root penetration and exploration of subsoil resources. In 2016 with the highest growing season rainfall $(449.9 \mathrm{~mm})$ irrigation of monoculture was most deleterious in $\mathrm{N} 0$ and N80 treatments (Figure 5c). The results revealed that the impact of irrigation on yield is significantly influenced by effect of the crop year as well interactions of tillage practices $\mathrm{x}$ forecrop $\mathrm{x}$ fertilization. Optimum yield from N80 in monoculture maize can be achieved without irrigation in average crop year and only in relatively dry year, is irrigation necessary, as in the case of 2015 (Figure 5b).

In 2017 significant yield declined from irrigation was observed in the control (N0) of MT in biculture (Figure $5 d$ ) and could be attributed to the crop year effect and high temperatures. According to Moraru and Teodor (2012) and Muñoz-Romero et al. (2015), soil temperature was strongly related to air temperature and it varied significantly with tillage system and time of the year and was higher in the mouldboard tillage than in the reduced and no-tillage system. The soil of biculture maize had higher organic matter content which increases the water holding capacity and contributes to the dark colour of the soil. These two soil properties increase its absorption of heat, thereby increasing the soil temperature (Fang et al., 2005). Increase in soil temperature leads to a decrease in the cation exchange capacity of the soil (Rengasmy and Churchman, 2009) and nutrient absorption is less root zone temperature dependent at higher external nutrient concentrations because the energy requirement for root absorption is diminished (Hagan, 1952).

Yield increment from increase in plant population density from 60,000 to 80,000 was significantly higher in MT $1.765 \mathrm{t} \mathrm{ha}^{-1}$, followed by ST 1.2175 and RT $1.0375 \mathrm{t} \mathrm{ha}^{-1}(\mathrm{MT}>\mathrm{ST}>\mathrm{RT})$. Mean yield gain from higher planting density (80,000 plants ha-1) was $12.8 \%$ $\left(1.2 \mathrm{t} \mathrm{ha}^{-1}\right)$ and statistically significant (Table 3).

Test of significance between planting densities

\section{Pairwise Comparisons \\ Dependent Variable: Yield}

\begin{tabular}{ccccccc} 
& & & & \multicolumn{2}{c}{ 95\% Confidence Interval for Difference } \\
(I) Plant_density & (J) Plant_density & Mean Difference (I-J) & Std. Error & Sig. & Lower Bound & Upper Bound \\
\hline 60000 plants & 80000 plants & $-1.189^{*}$ & .098 & .000 & -1.381 & -.997 \\
80000 plants & 60000 plants & $1.189^{*}$ & .098 & .000 & .997 & 1.381 \\
\hline
\end{tabular}

Based on estimated marginal means

*. The mean difference is significant at the 0.05 level.

b. Adjustment for multiple comparisons: Least Significant Difference (equivalent to no adjustments).

The increase in yield per unit area coincides with a $15.5 \%$ decline in grain productivity per plant at the higher density. Interaction of plant density $\mathrm{x}$ year $\mathrm{x}$ fertilization was statistically significant $(\mathrm{P}<0.05)$. Yield increment from 80,000 plant $\mathrm{ha}^{-1}$ was significantly higher in favorable crop year $(2016,2018)$ and higher fertilizer dosage (N160), however in unfavorable crop year, as in the case of 2015 , there was no significant yield increment from higher fertilizer dosage and 80,000 plants ha $^{-1}$ (Figure 6). Yield gain from higher planting density in 2015 was greater in the control (N0) and diminished with increase fertilizer dosages. The result demonstrated the deleterious effect of increase fertilizer dosage and high plant population density under unfavorable condition (limited water supply) and supported well documented research findings that lower fertilizer dosages were more effective under limited water supply and maximum yields for maize can be achieved at low plant density in drought years.

Figure 6: Planting density $\mathbf{x}$ year $\mathbf{x}$ fertilization interaction

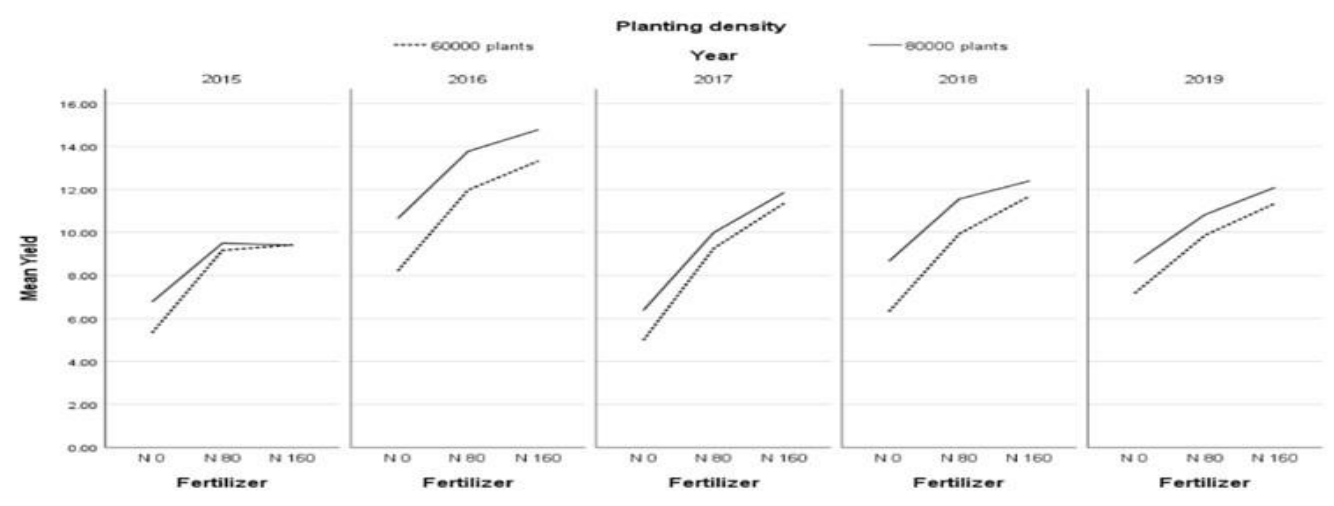


Fertilizer application significantly improved yield of maize and accounted for the largest yield variance $(35.8 \%)$ among the agrotechnical inputs. Yield differences between treatments were statistically significant (Table 4). Fertilizer use efficiency decreased significantly with higher dosage. Incremental yield gain from N80 was $3.16 \mathrm{t} \mathrm{ha}^{-1}$, compared to $\mathrm{N} 160$ with $4.28 \mathrm{ha}^{-1}$, a marginal 1.12 $\mathrm{t} \mathrm{ha}^{-1}$ increase for the additional $80 \mathrm{~kg} \mathrm{~N} \mathrm{ha}^{-1}$. Fertilizer $\mathrm{x}$ year interaction was significant $(\mathrm{P}<0.05)$; effect size of fertilizer treatments positively correlated with precipitation of the crop year. There was no significant difference in yield between N160 and N80 in 2015 as a result of low level of rainfall, especially during the reproductive phase of the crop (July). Similar observations were made by Nagy (2003) and Berényi et al. (2009) who reported that in years with insufficient water supplies, moderate fertilizer rates were more effective, compared to higher rates in years with adequate water supplies.

Fertilizer treatments pairwise comparison

$\begin{aligned} & \text { Dependent Variable: Yield } \\
& \text { LSD }\end{aligned}$
\begin{tabular}{clccccc} 
(I) Fertilizer & (J) Fertilizer & Mean Difference (I-J) & Std. Error & Sig. & \multicolumn{2}{c}{$\begin{array}{c}\text { L5\% Confidence Interval } \\
\text { Upper Bound }\end{array}$} \\
\hline $\mathrm{N} 0 \mathrm{~kg}$ & $\mathrm{~N} 80 \mathrm{~kg}$ & $-3.1626^{*}$ & .10440 & .000 & -3.3673 & -2.9579 \\
& $\mathrm{~N} 160 \mathrm{~kg}$ & $-4.2761^{*}$ & .10440 & .000 & -4.4808 & -4.0714 \\
$\mathrm{~N} 80 \mathrm{~kg}$ & $\mathrm{~N} 0 \mathrm{~kg}$ & $3.1626^{*}$ & .10440 & .000 & 2.9579 & 3.3673 \\
& $\mathrm{~N} 160 \mathrm{~kg}$ & $-1.1135^{*}$ & .10440 & .000 & -1.3182 & -.9088 \\
$\mathrm{~N} 160 \mathrm{~kg}$ & $\mathrm{~N} 0 \mathrm{~kg}$ & $4.2761^{*}$ & .10440 & .000 & 4.0714 & 4.4808 \\
& $\mathrm{~N} 80 \mathrm{~kg}$ & $1.1135^{*}$ & .10440 & .000 & .9088 & 1.3182 \\
\hline
\end{tabular}

Based on observed means.

The error term is Mean Square(Error) $=5.886$.

*. The mean difference is significant at the 0.05 level.

Interactions of irrigation $\mathrm{x}$ crop year $\mathrm{x}$ fertilization was significant $(\mathrm{P}<0.05)$. N160 was most responsive to irrigation treatment (Figure $7 a$ ) and yield increment was more pronounced in years with low levels of rainfall (2015 \& 2019) (Figure 7b). Nagy (2007) and Dóka \& Pepó (2009) reported similar results which revealed that irrigation had greater influence on the yield in a dry crop year, characterized by abiotic stress (moisture deficit), than in crop year with adequate water supply. Wang et al. (2019) and Csajbók et al.

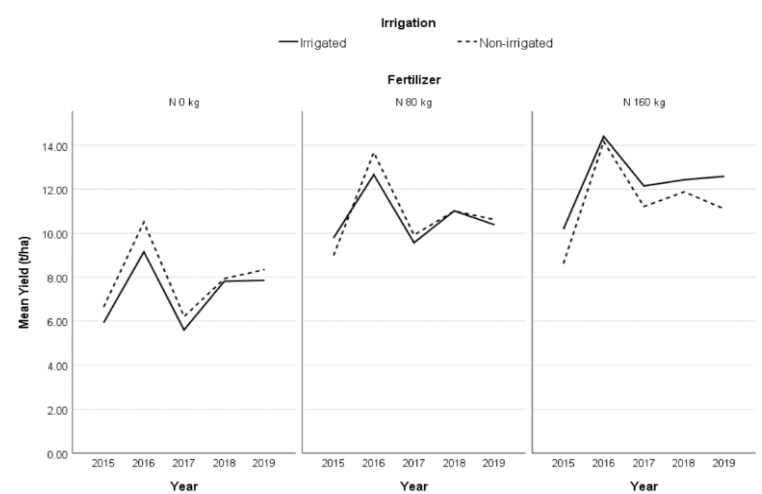

Crop rotation significantly improved yield of maize and reduce variation. Mean yield of maize cultivated in rotation with winter wheat forecrop was $24.7 \%(2.3$
(2014) found that higher dosages of fertilization improves water use efficiency (WUE) under limited water supply (water-stress) conditions. Only in 2015 which can be consider an unfavorable crop year was any significant benefit derived from irrigation of N80 (Figure $7 b$ ). The result suggest that the soil natural moisture content was adequate to sustain growth in the control (N0) and for utilization of N80 in all years, except 2015.

\section{Figure $7 b$ : Interaction of irrigation $\mathbf{x}$ fertilization on yield} increment

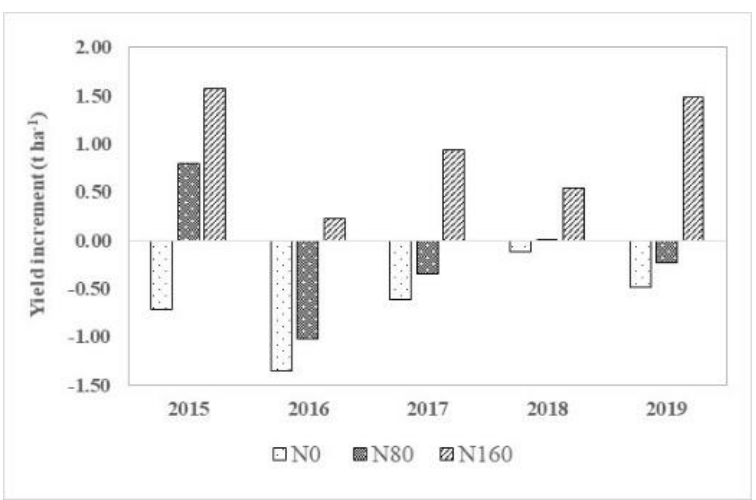

$\mathrm{t} \mathrm{ha}^{-1}$ ) higher than monoculture (range: 1.28-3.52 $\mathrm{t} \mathrm{ha}^{-1}$ ). Yield variation was greater in monoculture plots compared biculture $(\mathrm{RSD}=32 \%$ vs. $\mathrm{RSD}=22 \%)$. 
Forecrop $\mathrm{x}$ fertilization interaction was statistically significant $(\mathrm{P}<0.05)$ and influenced by crop year effect (Figure $8 a$ ). Yield surplus from crop rotation was highest in the control (N0) (Figure 8b) and decreased with increase fertilizer dosage. There was no significant difference in mean yield between N80 and N160

Figure 8a: Interaction of fertilizer, forecrop and year

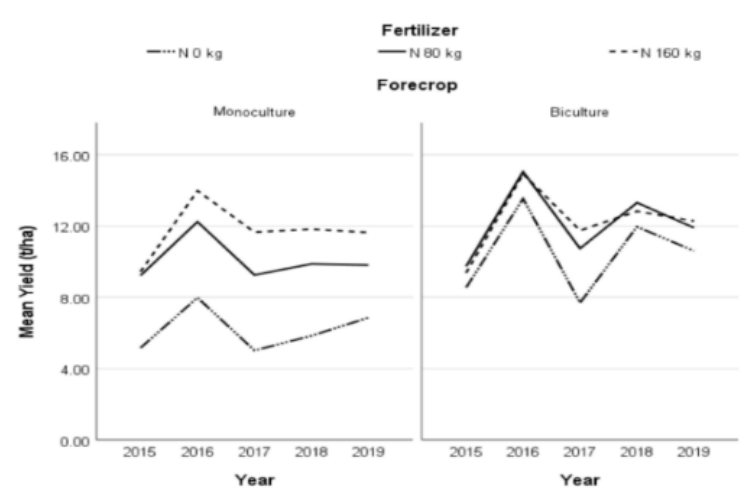

\section{CONCLUSIONS}

Generally, the results demonstrated that agrotechnical inputs in maize production system (tillage, fertilizer, irrigation, planting density, crop rotation) impacted to varying extent on yield and their effect size was modified by the prevailing weather condition of the crop year, mainly precipitation amount and distribution and temperature. Among the agrotechnical inputs, fertilizer had the largest impact on yield $(35.8 \%)$, followed by forecrop $(12.8 \%)$, planting density $(3.4 \%)$, tillage $(1.2 \%)$ and irrigation $(<1 \%)$. Higher planting density (80,000 plants ha $\left.\mathrm{ha}^{-1}\right)$ and fertilization rate $(\mathrm{N} 160)$ in tandem with MT are treatments combination conducive for high yield under favorable climatic conditions, whereas, in years with low rainfall and high temperatures, RT and ST offer treatment in biculture plots (12.14 vs. $\left.12.23 \mathrm{t} \mathrm{ha}^{-1}\right)$. Based on the results it is evident that crop rotation can aid in yield stability and buffer for a reduction in applied fertilizer rate of $28-77 \mathrm{~kg} \mathrm{~N} \mathrm{ha}^{-1}$ (mean $52.5 \mathrm{~kg}$ $\mathrm{ha}^{-1}$ ), with assumption of $22 \mathrm{~kg} \mathrm{~N} \mathrm{t}^{-1}$ grains.

Figure $8 b$ : Effect of fertilizer $\mathbf{x}$ forecrop interaction on yield increment

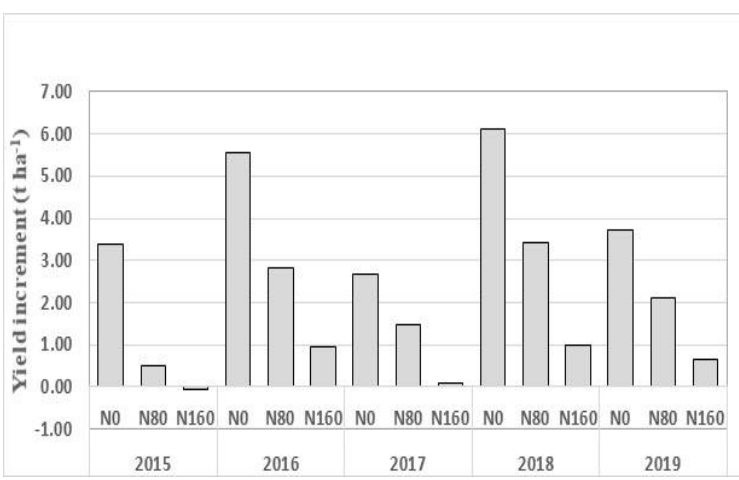

alternative to MT for optimum yield with 60,000 plants $\mathrm{ha}^{-1}$ and N80 treatment level.

Optimum yield from N80 kg ha-1 can be achieved without irrigation in normal crop year, however, fertilizer application rate should be determined based on nutrient status of the soil, tillage practices, plant density, as well as available water supply. The adverse effect of weather on yield can be mitigated through proper selection of the appropriate levels of agrotechnological inputs.

\section{ACKNOWLEDGEMENT}

The research was supported by the EFOP-3.6.3VEKOP-16-2017-00008 project and co-financed by the European Union and the European Social Fund.

\section{REFERENCES}

Abidela, H.M.-Muche, H.-Schmitter, P.-Nakawuka, P.-Tilahun, S.A.-Langan, S.-Barron, J.-Steenhuis, T.S. (2019): Deep Tillage Improves Degraded Soils in the (Sub) Humid Ethiopian Highlands. Land 2019, 8, 159.

Abuzar, M.R.-Sadozai, G.U.-Baloch, M.S.-Baloch, A.A.-Shah, I.Javaid, H.-Hussain. N. (2011): Effect of plant population densities on yield of maize. The Journal of Animal \& Plant Sciences, 21(4): 2011, 692-695.

Al-Kaisi, M.M.-Archontoulis, S.V.-Kwaw-Mensah, D.-Miguez, F. (2015): Tillage and crop rotation effects on corn agronomic response and economic return at seven Iowa locations. Agron. J. 107, 1411-1424.

Berényi, S.-Bertáné S.E.-Pepó P.-Loch J. (2009): Effect of fertilization and irrigation on $\mathrm{N}$ fractions determined in $0.01 \mathrm{M}$ calcium chloride on lowland pseudomyceliar chernozem. Agrokémia és talajtan. 58. 2: 251-264.

Berzsenyi, Z., (2010): Significance of the 50-year-old Long-term Experiments in Martonvasar. Acta Agronomica Hungarica, 58(Suppl.), pp. 23-34 (2010) DOI: 10.1556/AAgr.58. 2010. Suppl.1.4

Berzsenyi, Z.-Árendás, T-Bónis, P.-Micskei, G.-Sugár, E. (2011): Long-term effect of crop production factors on the yield and yield stability of maize (Zea mays L.) in different years. Acta Agronomica Hungarica. 59. 10.1556/AAgr.59.2011.3.1.

Bocz, E.-Nagy, J. (1981): Optimizing water and nutrient supply of maize and its effect on the weight of yield. Növénytermelés, 30. 6. 539-549. 
Brankatschk, G.-Finkbeiner, M. (2017): Crop rotations and crop residues are relevant parameters for agricultural carbon footprints. Agronomy for Sustainable Development. 2017; 37(6). [Google Scholar]

Csajbók, J.-Kutasy, E.-Pepó, P. (2014): The water use efficiency of maize depending on abiotic stress factors in field experiments. Columella - Journal of Agricultural and Environmental Sciences Vol. 1 (2014) 23-28.

Dóka, F.L.-Pepó, P. (2009): Yield and water balance of maize grown in rotation on chernozem soil. Cereal Research Communications. 37.4: 611-621.

Fang, C.M-Smith, P.-Monorieff, J.B. (2005): Similar response of Labile and resistant soil organic matter pools to changes in temperature. Nature. 2005;436: 881-883.

Grassini, P.-Thorburn, J.-Burr, C.-Cassman, K.G. (2011): Highyield irrigated maize in the Western U.S. Corn Belt: I. On-farm yield, yield potential, and impact of agronomic practices Field Crops Res., 120 (2011), pp. 142-150.

Hagan, R. M. (1952): Soil temperature and plant growth, p. 367-447. In: B.T. Shaw (ed.) Soil physical conditions and plant growth. Academic Press Inc., New York, N.Y.

Hatfield, L.J.-Dold, C. (2018): Climate Change Impacts on Corn Phenology and Productivity, Corn - Production and Human Health in Changing Climate, Amanullah and Shah Fahad, IntechOpen, DOI: 10.5772/intechopen.76933.

Hodges, J.A. (1931): "The Effect of Rainfall and Temperature on Corn Yields in Kansas." Journal of Farm Economics, vol. 13, no 2, 1931, pp. 305-318. JSTOR, www.jstor.org/stable/1229773. Accessed 10 June 2020.

Hungarian Central Statistical Office. http://www.ksh.hu/?lang=en accessed June $18^{\text {th }} 2020$

Inamullah, Rehman N.-Hussain, N.-Shah, S.-Arif, M. (2011) Correlations among grain yield and yield attributes in maize hybrids at various nitrogen levels. Sarhad J. Agric. Vol.27, No.4.

Kristo, I.-Matusek, N.-Máte, I (2013): Effect of cultivation systems on maize productivity and production profitability. Review on Agriculture and Rural Development 2013. vol. 2. (1) ISSN 2063-4803 pp. 28-32.

Li, Y.-Guan, K.-Schnitkey, G.-DeLucia, E.-Peng, B. (2019): Datasets for "Excessive rainfall leads to maize yield loss of a comparable magnitude to extreme drought in the United States". figshare. Dataset. https://doi.org/10.6084/m9.figshare.7581473.v1

Lobell, D.-Asner, G. (2003): Climate and management contributions to recent trends in U. S. agricultural yields. Science (80-). 2003;299: 1032 Available: http://www.sciencemag.org/content/299/5609/1032.short [PubMed] [Google Scholar]

Megyes, A.-Nagy, J.-Rátonyi, T.-Huzsvai, I. (2005): Irrigation of maize (zea mays 1.) in relation to fertilization in a long-term field experiment. Acta Agronomica Hungarica. 53.1:41-46.

Memon, S.Q.-Mirjat, M.S.-Mughal, A.Q.-Amjad, N. (2012): Effects of different tillage and fertilizer treatments on growth and yield components of maize. Pak. J. Agri., Agril. Engg., Vet. Sci., 2012, 28 (2): 160-176.

Moraru, P.-Teodor, R. (2012): Effect of tillage systems on soil moisture, soil temperature, soil respiration and production of wheat, maize and soybean crops. Journal of Food, Agriculture and Environment. 10. 445-448.

Muñoz-Romero, V.-Lopez-Bellido, L.-Lopez-Bellido, R.J. (2015): Effect of tillage system on soil temperature in a rainfed
Mediterranean Vertisol. Int. Agrophys., 2015, 29, 467-473. doi: 10.1515/intag-2015-0052.

Nagy, J. (2007): Evaluating the effect of year and fertilisation on the yield of mid ripening (FAO 400-499) maize hybrids. Cereal Research Communications. 35.3:1497-1507.

Nagy, J. (2012): The effect of fertilization and precipitation on the yield of maize (Zea mays L.) in a long-term experiment. Idojaras. 116. 39-52.

Nagy, J. (2003): Effect of Irrigation on Maize Yield (Zea mays L.). Acta Agraria Debreceniensis. 30-35. 10.34101/actaagrar/11/3441.

Pepó, P.-Vad, A.-Berenyi, S. (2008): Effects of irrigation on yields of maize (Zea mays L.) in different crop rotations. Cereal Research Communications. 2008. 36: Suppl. 5, 735-738.

Pepó, P.-Karancsi, G.L. (2014): new results of nutrient utilization and response of maize (Zea mays L.) hybrids. Columella Journal of Agricultural and Environmental Sciences Vol. 1, No. 2 (2014), 87-93.

Rengasmy, P.-Churchman, G.J. (2009): Cation exchange capacity, exchangeable cations and solidity. In: Peverrilli KI, et al. editors. Soil analysis. Australia: an interpretation manual CSIRO publishing; 2009.

Rogers, D.-Leikam, D.-Mengel, D (2007): Corn Production Handbook. Kansas State University Agricultural Experiment Station and Cooperative Extension Service. Accessed: http://www.ksre.ksu.edu/bookstore/pubs/c560.pdf

Sárvári, M. (2005): Impact of nutrient supply, sowing time and plant density on maize yields. Acta Agronomica Hungarica. 53. (1.): 59-70.

Sárvári, M.-Pepó, P. (2014): Effect of production factors on maize yield and yield stability. Cereal Research Communications. 42.4: 710-720.

Sharifi, R.S.-Sedghi, M..-Gholipouri., A. (2009): Effect of Population Density on Yield and Yield Attributes of Maize Hybrids. Research Journal of Biological Sciences Year: 2009 Volume: 4 Issue: pp. 475-379.

Schneider, F.-Don, A.-Hennings, I.-Schmittmann, O.-Seidel, S. (2017): The effect of deep tillage on crop yield - What do we really know?. Soil and Tillage Research. 174. 193-204. 10.1016/j.still.2017.07.005

Shivay, Y.S.-Singh, R.P. (2000): Growth, yield attributes, yields and nitrogen uptake of maize (Zea mays L.) as influenced by cropping systems and nitrogen levels. Annals Agriculture Research 21(4): 494-498.

Simić, M.-Videnović, Ž.-Dolijanović, Ž.-Jug, D.-Dumanović, Z. (2009): Maize growing under different tillage systems. $2^{\text {nd }}$ International Scientific/Professional Conference, Agriculture in Nature and Environment Protection, Vukovar, $4^{\text {th }}-6^{\text {th }}$ June, 62 67.

Shanti, K.V.P.-Rao, M.R.-Reddy, M.S.-Sarma, R.S. (1997): Response of maize (Zea mays) hybrid and composite to different levels of nitrogen. Indian J. Agric. Sci., 67: 424-425.

Sulyok, D.Z. (2005): Examining the efficiency of alternative tillage system. PhD thesis, Center for Agricultural and Applied Economic Sciences, University of Debrecen.

Tetio-Kagho, F.-Gardner, F.P. (1988): Responses of maize to plant population density.I. Canopy development, light relationships, andvegetative growth. Agronomy Journal, Madison, 80(5): 930935.

Tokatlidis, I.-Koutroubas, S.D. (2004). A review of maize hybrids' dependence on high plant populations and its implications for 
crop yield stability. Field Crops Research. 88. 103-114. 10.1016/j.fcr.2003.11.013.

Tollenaar, M.-McCullough, D.E.-Dwyer, L. M. (1994): Physiological basis of the genetic improvement of field crops. Marcel and Dekker Inc., New York, pp: 183-236.

Wang, X.-Zhou, B.-Sun, X.-Yue, Y.-Ma, W.-Zhao, M. (2015): Soil Tillage Management Affects Maize Grain Yield by Regulating Spatial Distribution Coordination of Roots, Soil Moisture and Nitrogen Status. PLoS One. 2015;10(6):e0129231. Published 2015 Jun 22. doi:10.1371/journal.pone.0129231
Wang, Y.-Zhang, X.-Chen, J.-Chen, A.-Wang, L.-Guo, X.-Niu, Y.-Liu, S.-Mi, G.-Gao, Q. (2019): "Reducing basal nitrogen rate to improve maize seedling growth, water and nitrogen use efficiencies under drought stress by optimizing root morphology and distribution," Agricultural Water Management, Elsevier, vol. 212(C), pages 328-337.

Wilhelm, W.W.-Wortmann, C.S. (2004): Tillage and rotation interactions for corn and soybean grain yield as affected by precipitation and air temperature. Agronomy Journal, 96: 425432. 
